\title{
Residual effect of nutrient integration on some selected soil chemical properties of the guinea savanna agro-ecological zone of Nigeria.
}

\author{
Olatunji, $\mathrm{O}^{1 *}$, S. A. Ayuba ${ }^{2}$ and A. $\mathrm{Ali}^{3}$ \\ ${ }^{(1,2,3)}$ Department of Soil Science, University of Agriculture, P.M.B. 2373, Makurdi, Benue State, Nigeria.
}

\begin{abstract}
The effects which integrated Nutrients (organic, inorganic and Biological Nitrogen fixer) had on soil chemical properties were evaluated after the conduct of the main experiment using maize as the experiment unit in 2008 and 2009. Treatments and treatment rates used were as follows. Poultry manure $\left(0,30\right.$ and 6 tha $\left.a^{-1}\right)$, NPK 20-10-10 (0, 150 and $\left.300 \mathrm{Kg} \mathrm{h}^{-1}\right)$, cowpea (ITAS EARLY). Treatments were combined pair-wise to give ten treatments. The experiments were conducted at the University of Agriculture, Makurdi, Teaching and Research Farm. The experimental design used was Randomized Complete Block Design (RCBD) and replication was done thrice. Plot size measured $3 \mathrm{mX} 4 \mathrm{~m}$ with an alley of $1 \mathrm{~m}$ between blocks and $0.5 \mathrm{~m}$ between plots. Maize was planted on rows spaced $75 \mathrm{~cm}$ apart and $50 \mathrm{~cm}$ within the row, three seeds were planted per hole and latter thinned to two plants per stand at 2 weeks after planting (2 WAP), this gave a total plant population of 53,333 plants per hectare. Before the on set of the experiment soil samples to a depth of 15 $\mathrm{cm}$ were collected to determine the physical and chemical properties of the soil. Soil samples were also analyzed at harvest in 2008 and 2009 to determine the chemical properties of the soil as affected by various treatment combinations. Integrated application of organic manure + NPK $20-10-10+$ Cowpea (ITAS EARLY) have positive impact $(P<0.05)$ on soil organic manure $(S O M)$, soil Nitrogen $P$, soil exchangeable cations in terms $\mathrm{K}, \mathrm{Ca}, \mathrm{Mg}$ and $\mathrm{Na}$. In 2009, the combination of $6 \mathrm{t} \mathrm{ha} \mathrm{a}^{-1}$ poultry manure $+300 \mathrm{~kg} \mathrm{ha}^{-1} \mathrm{NPK} 20-$ 10 - 10 gave the highest in terms of exchangeable bases $K, \mathrm{Ca}, \mathrm{Mg}, \mathrm{Na}\left(0.42,4.01,3.20\right.$ and $0.64 \mathrm{c} \mathrm{mol} \mathrm{\textrm {kg } ^ { - 1 }}$ respectively). For soil fertility sustenance 6 tha $a^{-1}$ poultry manure $+300 \mathrm{~kg} \mathrm{ha}^{-1} \mathrm{NPK} 20-10-10$ and cowpea (ITAS EARLY) will be recommended for the study area.
\end{abstract}

Keywords: Nutrient Integration, soil chemical properties, Integrated application, Savanna agro-ecological zone.

\section{Introduction}

Soil nutrient availability changes over time. The continuous recycling of nutrients into and out of the soil is known as the nutrient cycle (NRC, 1993). The cycle involves complex biological and chemical interactions. Smaling, 1993 suggested that nutrient cycle has two parts: "inputs" that add plant nutrients to the soil and "output" that export them from the soil largely in the form of harvested agricultural product. Important input sources include inorganic fertilizer, organic fertilizers such as manure, plant residues and cover crops, nitrogen generated by leguminous plants and atmospheric nitrogen deposition. Nutrients are exported from the field through harvest crops and alternative use of crop residues, as well as through leaching, atmospheric volatilization and erosion (Smaling et al., 1997; Alfaro et al., 2004).

The capacity of soils to be productive depends on more than just availability of plant nutrients. The physical, biological and chemical characteristics of a soil, its organic matter content, acidity texture, depth and water - retention capacity all influence fertility. Because these attributes differ among soils, soils differ in their quality (Ssali et al., 1986; Bekunda et al., 1997). The way soils are managed can improve or degrade the natural quality of soils. Mismanagement has led to the degradation of millions of areas of land through erosion, compaction, salinization, acidification and pollution by heavy metals (Gichuru et al., 2003). On the other hand, good management can limit physical losses and it includes use of cover crops and soil conservation measures; addition of organic matter to the soil, and judicious use of chemical fertilizers and pesticides (Gichuru et al., 2003).

Organic matter content is important for the proper management of soil fertility. Organic matter in soil helps plants grow by improving water holding capacity and drought resistance. In addition, organic matter permits better aeration, enhances the absorption and release of nutrients, and makes the soil less susceptible to leaching and erosion (Reijntjes et al., 1992, Sekhon and Meelu, 1994; Tulu, 2002). Plant needs a given quantity and mixture of nutrients to flourish. The higher the potentials to yield, the greater the nutrient requirement. A shortage of one or more nutrients can inhibit plant growth. Excess nutrients, especially those provided by inorganic fertilizers, can be wasteful, costly and in some instances, harmful to the environment (Pimental, 1996). 
In soil systems the difference between the volume of inputs and outputs constitute the nutrient balance. Positive nutrient balances in the soils occur when nutrient additions in the soil are greater then nutrients removals which indicates that the farming systems are efficient and sustainable. Negative balances could well indicate that the soils are being mined and that farming systems are unsustainable over time. The objective of this work is therefore to evaluate the contribution the various nutrient sources combination had on the soil chemical properties of the study area.

\section{Experimental site:}

\section{Material And Methods}

The field experiments were sited at the Experimental Farm of the University of Agriculture, Makurdi $\left(7^{0} 41^{\prime} \mathrm{N}, 8^{0} 35^{\prime} \mathrm{E}\right)$ in the Southern guinea agro - ecological zone of Nigeria. The soils are classified as typical ulstropept.

\section{Treatments and field experiment:}

The experiments were conducted during the 2008 and 2009 cropping seasons and were laid out in a randomized complete block design with three replications. The plot size was $4 \mathrm{~m} \mathrm{X} 3 \mathrm{~m}$. The treatments consisted of three rates of NPK $20-10-10\left(0,150,300 \mathrm{~kg} \mathrm{ha}^{-1}\right)$, three rates of poultry manure $(0,3$ and $6 \mathrm{t}$ ha ${ }^{1}$ ) and cowpea variety (ITAS EARLY). The sites were manually cleared using cutlass and later ridged with hoe. Poultry manure $\left(0,3\right.$ and $\left.6 \mathrm{t} \mathrm{ha}^{-1}\right)$ were uniformly spread on top of the ridge $0.75 \mathrm{~m}$ apart and incorporated into the soil with hoe 2 weeks before planting. Planting of maize was done at a spacing of $0.75 \mathrm{~cm}$ plant to plant with tow sends per stand after thinning which gave a total plant population of about 53,333 plants per hectare. The balance of NPK 20-10-10 fertilizer in the treatments combination with manure was applied 5 weeks after planting (WAP) to the respective maize plants using band application method.

The treatment combinations were as follows:

\begin{tabular}{|c|c|c|}
\hline $\mathrm{Co}$ & - & Control \\
\hline $\mathrm{P}_{0} \mathrm{~F}_{1}$ & - & Cowpea varieties \\
\hline $\mathrm{P}_{0} \mathrm{~F}_{1}$ & - & $150 \mathrm{~kg} \mathrm{ha}^{-1}$ NPK $20-10-10$ \\
\hline $\mathrm{P}_{0} \mathrm{~F}_{2}$ & - & $300 \mathrm{~kg} \mathrm{ha}^{-1} \mathrm{NPK} 20-10-10$ \\
\hline $\mathrm{P}_{1} \mathrm{~F}_{0}$ & - & $3 \mathrm{t} \mathrm{ha}^{-1}$ Poultry manure \\
\hline $\mathrm{P}_{1} \mathrm{~F}_{1}$ & - & $3 \mathrm{t} \mathrm{ha}^{-1}$ Poultry manure $+150 \mathrm{~kg} \mathrm{ha}^{-1}$ NPK $20-10-10$ \\
\hline $\mathrm{P}_{1} \mathrm{~F}_{2}$ & - & $3 \mathrm{t} \mathrm{ha}^{-1}$ Poultry manure $+300 \mathrm{~kg} \mathrm{ha}^{-1}$ NPK $20-10-10$ \\
\hline $\mathrm{P}_{2} \mathrm{~F}_{0}$ & - & $6 \mathrm{t} \mathrm{ha}^{-1}$ Poultry manure \\
\hline $\mathrm{P}_{2} \mathrm{~F} 1$ & - & $6 \mathrm{t} \mathrm{ha}^{-1}$ Poultry manure $+150 \mathrm{~kg} \mathrm{ha}^{-1}$ NPK $20-10-10$ \\
\hline $\mathrm{P}_{2} \mathrm{~F}_{2}$ & - & $6 \mathrm{t} \mathrm{ha}^{-1}$ Poultry manure $+300 \mathrm{~kg} \mathrm{ha}^{-1}$ NPK $20-10-10$ \\
\hline
\end{tabular}

\section{Soil sampling and sample preparation.}

Before the onset of the experiment in 2008 surface $(10-15 \mathrm{~cm})$ soil samples were collected from 8 points using soil auger and bulked. At harvest soil samples were taken from each plot based on the treatment applied. A total of 40 samples 20 each for 2008 and 2009 respectively. The soil sampled before research work commenced in 2008 and at harvest were air dried at NICANSOL laboratory for 3 days. The soil samples were crushed and sieved through a $2 \mathrm{~mm}$ sieve. Various chemical and physical properties of soils were thereafter determined.

\section{Soil and poultry manure analysis.}

The particle size distribution of the soil was carried out using Hydrometer method (Bouyoucos, 1951), while soil $\mathrm{pH}$ was measured with the glass electrode in soil solution ratio of 1:2 in $0.01 \mathrm{M} \mathrm{Ca} \mathrm{Cl}_{2}$. Soil Organic carbon (OC) was determined using the Walkley - Black (1934) method and the total $\mathrm{N}$ by the micro - kjeldahl digestion method (Bremner and Mulvaney, 1982) after digestion of samples with concentrated $\mathrm{H}_{2} \mathrm{SO}_{4}$. Available $\mathrm{P}$ was determine using Bray and Kurtz, (1945) extraction method. Exchangeable cations were extracted using $1 \mathrm{~N} \mathrm{NH}_{4} \mathrm{OAC}$ solution with $\mathrm{K}$ and $\mathrm{Na}$ read using flame photometer, while $\mathrm{Ca}$ and $\mathrm{Mg}$ were determined on the atomic absorption spectrophotometer. Cation exchange capacity (CEC) was established as summation of the exchangeable cations ( $\mathrm{K}, \mathrm{Na}, \mathrm{Ca}$ and $\mathrm{Mg}$ ). The poultry manure used for the experiment was collected in dried form from a broiler poultry pen. The nitrogen of the poultry manure sample was determined using micro kjeldahl method. For the determination of $\mathrm{P}, 5 \mathrm{ml}$ of sample solution from wet digestion was used. Phosphorus was determined using Vanado - Molybdate colorimetry method. The $\mathrm{K}, \mathrm{Ca}$ and $\mathrm{Na}$ in the sample were determined using flame photometer (AO AC, 1990), and $\mathrm{Mg}$ was determined using Atomic Absorption spectrometer (AAS). 


\section{Data Analysis}

The statistical analysis was performed using SPSS statistical package for the analysis of variance (ANOVA). Means were separated using fisher's least significant difference. FLSD at 0.05 level of probability where $\mathrm{F}$ - ratio was significant.

\section{Poultry manure and soil properties}

\section{Results}

The poultry manure contained $14.8 \% \mathrm{C}, 2.42 \% \mathrm{~N}, 1.65 \% \mathrm{P}, 2.45 \% \mathrm{~K}, 16.50 \% \mathrm{Ca}$ and $0.75 \% \mathrm{Mg}$. The physical and chemical properties of the soil on which the experiments were carried out are shown in Table 1. The soil was sandy loam, slightly acidic and very low in organic $\mathrm{C}$, the total $\mathrm{N}$ was very low and the available $\mathrm{P}$ and exchangeable $\mathrm{K}$ values were low for the production of maize. Integration of poultry manure, NPK $20-10$ -10 and cowpea (ITAS EARLY) had significant impact $(\mathrm{P}<0.05)$ on soil chemical properties for the two years of the study.

\section{Organic matter content of the soil.}

The contribution, the application of poultry manure + NPK 20-10-10+ cowpea (ITAS EARLY) made to the SOM is shown in Table 2.

In 2008 the contribution of $6 \mathrm{t} \mathrm{ha}^{-1}$ poultry manure was the highest $(3.12 \%)$, followed by $6 \mathrm{t} \mathrm{ha}^{-1}$ poultry manure $+150 \mathrm{~kg} \mathrm{ha}^{-1}$ NPK $20-10-10(2.99 \%)$ and treatment $6 \mathrm{t} \mathrm{ha}^{-1}$ poultry manure $+300 \mathrm{~kg} \mathrm{ha}^{-1}$ NPK $20-10-10$ gave the third highest $(2.82 \%)$ in 2009 . The highest SOM was obtained from $6 \mathrm{t} \mathrm{ha}^{-1}$ poultry manure $+300 \mathrm{~kg} \mathrm{ha}^{-1} \mathrm{NPK} 20-10-10(2.82 \%)$, it was followed by $6 \mathrm{t} \mathrm{ha}^{-1}$ poultry manure $+150 \mathrm{~kg} \mathrm{ha}^{-1}(3.44$ $\%)$. The lowest SOM concentration was obtained from the control; $1.28 \%$ and $1.12 \%$ for 2008 and 2009 respectively.

\section{Soil Nitrogen and Available Phosphorus}

The result presented in Table 2 shows that the applied treatments significantly increased soil Nitrogen and available Phosphorus. In 2008 for soil nitrogen the combination of $6 \mathrm{tha}^{-1}$ poultry manure $+300 \mathrm{~kg} \mathrm{ha}^{-1} \mathrm{NPK}$ $20-10-10+$ cowpea (ITAS EARLY) gave the highest total N $(0.15 \%)$, it was followed by treatment $3 \mathrm{tha}^{-1}$ poultry manure $+300 \mathrm{~kg} \mathrm{ha}^{-1}$ NPK $20-10-10+$ cowpea (ITAS EARLY) $(0.13 \%)$. In 2009, the trend did not followed the same pattern observed in 2008, the combination of $6 \mathrm{t} \mathrm{ha}^{-1}$ poultry manure $+300 \mathrm{~kg} \mathrm{ha}^{-1} \mathrm{NPK} 20-$ $10-10+$ cowpea (ITAS EARLY) $(0.18 \%)$, this was followed by $3 \mathrm{t} \mathrm{ha}^{-1}$ poultry manure $+300 \mathrm{~kg} \mathrm{ha}^{-1} \mathrm{NPK} 20$ $-10-10(0.17 \%)$, the third highest value was obtained from $6 \mathrm{t} \mathrm{ha}^{-1}$ poultry manure + cowpea (ITAS EARLY) $(0.15 \%)$.

Table 1: Soil physical and chemical properties before planting

\begin{tabular}{lc}
\hline Properties & Values \\
\hline $\mathrm{pH}\left(\mathrm{H}_{2} \mathrm{O}\right)$ & 6.20 \\
$\mathrm{pH}\left(\mathrm{CaCl}_{2}\right)$ & 5.90 \\
$\%$ sand & 75.60 \\
\% Silt & 17.20 \\
\% Clay & 7.20 \\
Textural Class & Sandy loam \\
$\mathrm{N}(\mathrm{g} \mathrm{Kg}-1)$ & 0.09 \\
$\mathrm{P}(\mathrm{mg} \mathrm{Kg}-1)$ & 2.15 \\
$\mathrm{~K}(\mathrm{c} \mathrm{mol} \mathrm{Kg}-1)$ & 0.22 \\
$\mathrm{Ca}(\mathrm{c} \mathrm{mol} \mathrm{Kg-1)}$ & 2.60 \\
$\mathrm{Mg}(\mathrm{c} \mathrm{mol} \mathrm{Kg}-1)$ & 2.48 \\
$\mathrm{Na}(\mathrm{c} \mathrm{mol} \mathrm{Kg}-1)$ & 0.31 \\
$\mathrm{CEC} \mathrm{(c} \mathrm{mol} \mathrm{Kg-1)}$ & 6.48 \\
$\mathrm{OC}(\mathrm{g} \mathrm{Kg}-1)$ & 1.25 \\
$\mathrm{OM}(\mathrm{g} \mathrm{Kg}-1)$ & 1.45 \\
\hline
\end{tabular}

In 2008 for soil available phosphorus $6 \mathrm{t} \mathrm{ha}^{-1}$ poultry manure + cowpea (ITAS EARLY) gave highest value $\left(6.85 \mathrm{mg} \mathrm{kg}^{-1}\right)$, it was followed by $6 \mathrm{t} \mathrm{ha}^{-1}$ poultry manure $+150 \mathrm{~kg} \mathrm{ha}$ NPK $20-10-10+$ cowpea (ITAS EARLY) $\left(6.31 \mathrm{mg} \mathrm{kg}^{-1}\right)$ and the third highest value obtained from $6 \mathrm{t} \mathrm{ha}^{-1}$ poultry manure $+300 \mathrm{~kg} \mathrm{ha}^{-}$ ${ }^{1}$ NPK $20-10-10+$ cowpea (ITAS EARLY), $\left(6.25 \mathrm{mg} \mathrm{kg}^{-1}\right)$. In 2009 there was a change in the trend observed. The combination of $6 \mathrm{t} \mathrm{ha}^{-1}$ poultry manure $+300 \mathrm{~kg} \mathrm{ha}^{-1} \mathrm{NPK} 20-10-10$ and cowpea (ITAS EARLY), (7.92 mg kg $\mathrm{mg}^{-1}$ ), this was followed by treatments $6 \mathrm{t} \mathrm{ha}^{-1}$ poultry manure + cowpea (ITAS EARLY) 
$\left(7.08 \mathrm{mg} \mathrm{kg}^{-1}\right)$. All the treatment gave higher value of plant available phosphorus than the initial soil value except the control.

\section{Soil Exchangeable Bases}

The combined application of poultry manure, NPK $20-10-10$ and cowpea (ITAS EARLY) had significant effect on soil exchangeable $\mathrm{K}, \mathrm{Ca}, \mathrm{Mg}$ and $\mathrm{Na}$ has presented in Table 3. In 2008 the combination $6 \mathrm{t}$

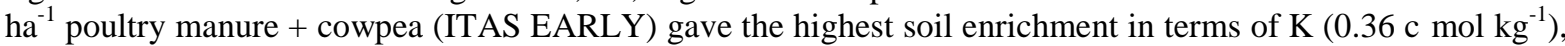
$\mathrm{Ca}\left(3.64 \mathrm{c} \mathrm{mol} \mathrm{kg}^{-1}\right)$ and $\mathrm{Mg}\left(3.02 \mathrm{c} \mathrm{mol} \mathrm{kg}{ }^{-1}\right)$ while the combination of $3 \mathrm{t} \mathrm{ha}^{-1}$ poultry manure $+300 \mathrm{~kg} \mathrm{ha}^{-1}$ NPK $20-10-10$ and $6 \mathrm{tha}^{-1}$ poultry manure $+30 \mathrm{~kg} \mathrm{ha}^{-1} \mathrm{NPK}+20-10-10$ gave the highest in terms of soil $\mathrm{Na}\left(0.58 \mathrm{c} \mathrm{mol} \mathrm{kg}^{-1}\right)$ in 2008. While in 2009, the combination of $6 \mathrm{tha}^{-1}$ poultry manure $+300 \mathrm{~kg} \mathrm{ha}^{-1} \mathrm{NPK} 20-$ $10-10$ gave the highest in terms of all the soil exchangeable bases considered; $\mathrm{K}\left(0.42 \mathrm{c} \mathrm{mol} \mathrm{kg}^{-1}\right), \mathrm{Ca}(4.01 \mathrm{c}$ mol kg$\left.{ }^{-1}\right), \mathrm{Mg}\left(3.32 \mathrm{c} \mathrm{mol} \mathrm{kg}^{-1}\right)$ and $\mathrm{Na}\left(0.64 \mathrm{c} \mathrm{mol} \mathrm{kg}^{-1}\right)$. In both year of the study all treatment combinations gave highest value in terms of enrichment when compared with the control. Invariably, the least values were obtained from the controls.

Table 2: Effects of poultry manure, NPK 20:10:10 and cowpea variety

(ITAS EARLY) on some selected soil chemical properties.

\begin{tabular}{|c|c|c|c|c|c|c|}
\hline \multirow{3}{*}{ Treatments } & \multicolumn{2}{|c|}{2008} & \multicolumn{4}{|c|}{2009} \\
\hline & $\mathrm{OM}$ & $\mathrm{N}$ & $\mathrm{P}$ & $\mathrm{OM}$ & $\mathrm{N}$ & $\mathrm{P}$ \\
\hline & $\left(\mathrm{mg} \mathrm{kg}^{-1}\right)$ & $(\%)$ & $\left(\mathrm{mg} \mathrm{kg}^{-1}\right)$ & $\left(\mathrm{mg} \mathrm{kg}^{-1}\right)$ & $(\%)$ & $\left(\mathrm{mg} \mathrm{kg}^{-1}\right)$ \\
\hline $\mathrm{C}_{0}$ & 1.28 & 0.08 & 4.15 & 1.12 & 0.06 & 3.65 \\
\hline $\mathrm{P}_{0} \mathrm{~F}_{0}$ & 1.48 & 0.11 & 4.25 & 1.38 & 0.13 & 4.02 \\
\hline $\mathrm{P}_{0} \mathrm{~F}_{1}$ & 1.84 & 0.12 & 4.72 & 1.58 & 0.11 & 4.72 \\
\hline $\mathrm{P}_{0} \mathrm{~F}_{2}$ & 2.02 & 0.12 & 5.02 & 1.77 & 0.14 & 5.22 \\
\hline $\mathrm{P}_{1} \mathrm{~F}_{0}$ & 2.76 & 0.11 & 4.88 & 3.02 & 0.12 & 5.82 \\
\hline $\mathrm{P}_{1} \mathrm{~F}_{1}$ & 2.41 & 0.13 & 4.88 & 2.46 & 0.13 & 5.31 \\
\hline $\mathrm{P}_{1} \mathrm{~F}_{2}$ & 2.23 & 0.14 & 5.68 & 2.55 & 0.17 & 5.28 \\
\hline $\mathrm{P}_{2} \mathrm{~F}_{0}$ & 3.12 & 0.13 & 6.85 & 3.44 & 0.15 & 7.08 \\
\hline $\mathrm{P}_{2} \mathrm{~F}_{1}$ & 2.99 & 0.13 & 6.31 & 3.48 & 0.14 & 7.08 \\
\hline $\mathrm{P}_{2} \mathrm{~F}_{2}$ & 2.82 & 0.15 & 6.25 & 3.65 & 0.18 & 7.92 \\
\hline $\mathrm{F}-\mathrm{LSD}(0.05)$ & 0.58 & 0.04 & 1.12 & 0.62 & 0.06 & 1.83 \\
\hline
\end{tabular}

Key:

$\mathrm{P}$ - poultry manure $\left(0,1\right.$, and $2-0 \mathrm{t}, 3 \mathrm{t}$ and $\left.6 \mathrm{t} \mathrm{ha}^{-1}\right)$

F- NPK 20-10-10 (0, 1 and 2- $0 \mathrm{Kg}, 150 \mathrm{Kg}$ and $\left.300 \mathrm{Kg} \mathrm{ha}^{-1}\right)$

$\mathrm{C}_{0^{-}}$Control (No P, no F, no cowpea)

Table 3: Effects of poultry manure, NPK 20:10:10 and cowpea variety (ITAS EARLY) on exchangeable bases of the soil after the trials.

\begin{tabular}{|c|c|c|c|c|c|c|c|c|}
\hline \multirow[b]{2}{*}{ Treatments } & \multirow[b]{2}{*}{ K } & \multirow[b]{2}{*}{$\mathrm{Ca}$} & \multicolumn{4}{|c|}{2008} & \multicolumn{2}{|r|}{2009} \\
\hline & & & $\mathrm{Mg}$ & $\begin{array}{c}\mathrm{Na} \\
\mathrm{cmol} \mathrm{mg}^{-1} \\
\end{array}$ & K & $\mathrm{Ca}$ & $\mathrm{Mg}$ & $\mathrm{Na}$ \\
\hline $\mathrm{C}_{0}$ & 0.22 & 2.51 & 2.40 & 0.30 & 0.18 & 2.52 & 2.10 & 0.26 \\
\hline $\mathrm{P}_{0} \mathrm{~F}_{0}$ & 0.27 & 2.75 & 2.51 & 0.33 & 0.29 & 3.05 & 2.62 & 0.34 \\
\hline $\mathrm{P}_{0} \mathrm{~F}_{1}$ & 0.25 & 2.85 & 2.46 & 0.42 & 0.25 & 3.01 & 2.64 & 0.48 \\
\hline $\mathrm{P}_{0} \mathrm{~F}_{2}$ & 0.26 & 2.77 & 2.52 & 0.51 & 0.30 & 2.70 & 2.62 & 0.51 \\
\hline $\mathrm{P}_{1} \mathrm{~F}_{0}$ & 0.27 & 2.82 & 2.53 & 0.38 & 0.28 & 3.02 & 2.83 & 0.42 \\
\hline $\mathrm{P}_{1} \mathrm{~F}_{1}$ & 0.29 & 2.93 & 2.61 & 0.56 & 0.33 & 3.31 & 2.91 & 0.59 \\
\hline $\mathrm{P}_{1} \mathrm{~F}_{2}$ & 0.31 & 3.01 & 2.52 & 0.58 & 0.35 & 3.28 & 2.63 & 0.62 \\
\hline $\mathrm{P}_{2} \mathrm{~F}_{0}$ & 0.36 & 6.64 & 3.02 & 0.57 & 0.39 & 3.98 & 3.08 & 0.64 \\
\hline $\mathrm{P}_{2} \mathrm{~F}_{1}$ & 0.32 & 3.29 & 2.62 & 0.58 & 0.39 & 3.86 & 3.02 & 0.62 \\
\hline $\mathrm{P}_{2} \mathrm{~F}_{2}$ & 0.10 & 3.55 & 3.08 & 0.61 & 0.42 & 4.01 & 3.32 & 0.64 \\
\hline $\mathrm{F}-\operatorname{LSD}(0.05)$ & 0.10 & 0.76 & 0.40 & 0.28 & 0.13 & 0.81 & 0.46 & 0.28 \\
\hline
\end{tabular}

Key:

$\mathrm{P}$ - poultry manure $\left(0,1\right.$, and $2-0 \mathrm{t}, 3 \mathrm{t}$ and $\left.6 \mathrm{t} \mathrm{ha}^{-1}\right)$

F- NPK 20-10-10 (0, 1 and 2- $0 \mathrm{Kg}, 30 \mathrm{Kg}$ and $\left.60 \mathrm{Kg} \mathrm{ha}^{-1}\right)$

$\mathrm{C}_{0^{-}}$Control (No P, no F, no cowpea)

\section{Discussion}

The result of this work has established the fact that the application of poultry manure, NPK $20-10-$ 10 and cowpea (ITAS EARLY) has significant impact on SOM, total N, available P and soil exchangeable bases $(\mathrm{K}, \mathrm{Ca}, \mathrm{Mg}$ and Na). The concentration of SOM obtained in 2009 indicated the cumulative effects of the applied higher rates of the fertilizer materials used which probably resulted in the protection of $\mathrm{C}$ and $\mathrm{N}$ from 
mineralization and hence increase soil surface concentration of OM. The work of (Palm et al., 1997) emphasized the effects of organic materials on nutrient availability and acquisition. Eghball, (2002) also reported higher SOM with application of compost than with non - composted treatments. The trend observed for soil nitrogen and phosphorus was similar to that of SOM, the positive influence of combined poultry manure + NPK $20-10-10$ and cowpea (ITAS EARLY) had on soil nutrient dynamics corroborates the results reported by Owaiye (1993); Fauci and Dick (1994) and Eghball, (2002). This seems to suggest that SOM is paramount in sustaining other soil quality factor (Robinson et al., 1994). The residual effect of combined application of poultry manure + NPK 20-10-10 and cowpea (ITAS EARLY) had impact on K, Ca, Mg, Na due to benefit of soil nutrient made available by cowpea residues, prevention of leaching out of NPK $20-10-10$ nutrient by the poultry manure component in addition to nutrient component of the poultry manure that takes long to mineralize completely as suggested by the work of Palm et al (1997), that explained the influence of organic materials on not mineralization - immobilization patterns.

\section{Conclusion}

For plant nutrition and especially soil fertility maintenance, the integration of poultry manure $\left(6 \mathrm{t} \mathrm{ha}^{-1}\right)$ + NPK $20-10-10\left(300 \mathrm{~kg} \mathrm{ha}^{-1}\right)$ and cowpea (ITAS EARLY) should be advocated and encouraged in the study area.

\section{References}

[1]. Alfaro, M. A. Jarvis, S. C. and Gregory, P.J. 2004. Factors affecting leaching in different soils. Soil use and management. 20 : 182 189

[2]. AOAC. (1990). Official methods of analysis Association of official analytical chemists, Washington DC., Pp. 123 - 126

[3]. Bekunda, M. A., Bationa, A., and Ssali, A. (1997). Soil fertility management in Africa. A review of selected research trails. In: Burresh, P.J., Sanchez. P. A., Calhour, F. (eds) replenishing soil fertility in African. Soil science society of American special publication No. 51. Soil Science Society of American, American Society of Agronomy, Madison, Wisconsin, USA Pp. 63 - 79.

[4]. Bremner, J. S and Mulraney, C.S (1982). Nitrogen total. In: Methods of soil analysis, part 2 chemical and microbial properties. Page, $\mathrm{Al}$ (ed.) $2^{\text {nd }}$ ed. Agronomy monograph No. 9 American Society of Agronomy, Madison, WL, ISBN: $0-89118-810-\mathrm{X}$ Pp : $100-224$

[5]. Bray, R. H and Kurtz, L.T. (1945). Determination of total organic and available forms of phosphorus in soils. Soil Science 59 : 39 45

[6]. Eghball, B. (2002). Soil properties as influenced by phosphorus and nitrogen - based manure and compost applications. Agron. J. $94: 128-135$

[7]. Fauci, M. F and Dick, R. P (1994). Plant response to organic amendment and decreasing inorganic nitrogen rates in soil from a long - term experiment. Soil Science society of American Journal $58: 134-138$.

[8]. Gichuru, M. P., Bationo, A., Bekunda, M.A (2003). Soil fertility management in African: A regional perspective CTA 322Pp. ISBN: $9966-24-063-2$

[9]. NRC (National Research Council). (1995). Soil and water quality: An agenda for agriculture. Washington DC: National Academy Press.

[10]. Owaiye, A. R (1993). Effect of residue mulch on characteristics and productivity of two soil classes under coffee in Nigeria. In soil organic matter dynamics and sustainability of tropical agriculture K Mulongy and R Mereks (eds.) J. Wiley Chichester.

[11]. Palm, C. A., Myers, R.J.K and Nandwa, S. (1991) combined use of organic and inorganic nutrient sources for soil fertility maintenance and replenishment. In: Buresh, R, Sanchez, P.A., Calboun, F (eds.). Replenishing soil fertility in Africa. Soil science society of American special publication No. 51. soil science society of American, American society of Agronomy, Madison, Wisconsin, USA Pp. $193-217$.

[12]. Pimental, D. (1996). Green Revolution and chemical Hazards. Sci. Total environ. $188: 86-88$.

[13]. Reijntjes, C.B., Haverkert and Waters, A. Bayer (1992). Farming for the future: An introduction to low - external - input and sustainable agriculture. London: Macmillan Press Ltd. Robinson, C. A., Cruse, R. M and Chaffarzadch, M. (1996). Cropping system and nitrogen effects on Mollisol organic carbon. Soil sci. Soc Am. J 60: 264 - 269

[14]. Sekhon, Gos and Meelu, O. P. (1994). Organic matter management in relation to crop production in stressed rain fed systems. In stressed ecosystems and sustainable agriculture, ed. S.M. Virmarmi, J.C Katyal H. Eswaran and J.P Abrol. New Delhii Oxford University Press and IBH Publishing Smaling, E. M. A, Nandwa, S. M., Janssen, B. H (1997). Soil fertility in Africa is at stake in: Buresh, R. J., Sanchez, P. A., Calhoun, F. (eds.) replenishing soil fertility in Africa. Soil science ociety of American, American society of Agronomy, Madison, Wisconsin, USA Pp $42-61$.

[15]. Ssali, H., Keya, S. O. and Ellis, M. A. (1986) influence of phosphorus application rates and placement on the nodulation growth and yield of beans and soy beans grown at two nitrogen levels. Kenya J. Sci. Tech. $2: 91-98$.

[16]. Tulu, T. (2002) soil and water conservation for sustainable agriculture. CTA, 155 Pp ISBN: 14068011059

[17]. Walkley, A. and Black, C. A. (1934). An examination of the Degtjrareff method for determining soil organic matter and a proposal modification of chronic acid titration method. Soil Sci. $37: 29-38$. 